\title{
An improved methodology for the recovery of Zea mays and other large crop pollen, with implications for environmental archaeology in the Neotropics
}

Article

Accepted Version

Whitney, B. S., Rushton, E. A. C., Carson, J. F., Iriarte, J. and Mayle, F. E. (2012) An improved methodology for the recovery of Zea mays and other large crop pollen, with implications for environmental archaeology in the Neotropics. The Holocene, 22 (10). pp. 1087-1096. ISSN 0959-6836 doi: https://doi.org/10.1177/0959683612441842 Available at https://centaur.reading.ac.uk/32925/

It is advisable to refer to the publisher's version if you intend to cite from the work. See Guidance on citing.

To link to this article DOI: http://dx.doi.org/10.1177/0959683612441842

Publisher: Sage Publications

All outputs in CentAUR are protected by Intellectual Property Rights law, including copyright law. Copyright and IPR is retained by the creators or other copyright holders. Terms and conditions for use of this material are defined in the End User Agreement. 


\section{www.reading.ac.uk/centaur}

\section{CentAUR}

Central Archive at the University of Reading

Reading's research outputs online 


\section{An improved methodology for the recovery of Zea mays and other large crop pollen, with implications for environmental archaeology in the Neotropics}

Bronwen S. Whitney ${ }^{1 *}$, Elizabeth A. C. Rushton ${ }^{2}$, John F. Carson ${ }^{3,1}$, Jose Iriarte ${ }^{4}$, and Francis E. Mayle $^{3}$

${ }^{1}$ School of Geosciences, The University of Edinburgh, Drummond St., Edinburgh EH8 9XP, UK ${ }^{2}$ School of Geography, The University of Nottingham, University Park, Nottingham NG7 2RD, UK

${ }^{3}$ School of Archaeology, Geography and Environmental Science, The University of Reading, Whiteknights, Reading RG6 6AB, UK

${ }^{4}$ Department of Archaeology, College of Humanities, University of Exeter, Exeter EX4 4QE, UK *Corresponding author, email: b.whitney@ed.ac.uk tel: $+44(0) 1316509140$ fax: $+44(0) 1316502524$

\section{A. Abstract}

We present a simple sieving methodology to aid the recovery of large cultigen pollen grains, such as maize (Zea mays L.), manioc (Manihot esculenta Crantz), and sweet potato (Ipomoea batatas L.), among others, for the detection of food production using fossil pollen analysis of lake sediments in the tropical Americas. The new methodology was tested on three large study lakes located next to known and/or excavated pre-Columbian archaeological sites in South and Central America. Five paired samples, one treated by sieving, the other prepared using standard methodology, were compared for each of the three sites. Using the new methodology, chemically-digested sediment samples were passed through a $53 \mu \mathrm{m}$ sieve, and the residue was retained, mounted in silicone oil, and counted for large cultigen pollen grains. The filtrate was mounted and analysed for pollen according to standard palynological procedures. Zea mays (L.) was recovered from the sediments of all three study lakes using the sieving technique, where no cultigen pollen had been previously recorded using the standard 
methodology. Confidence intervals demonstrate there is no significant difference in pollen assemblages between the sieved versus unsieved samples. Equal numbers of exotic Lycopodium spores added to both the filtrate and residue of the sieved samples allow for direct comparison of cultigen pollen abundance with the standard terrestrial pollen count. Our technique enables the isolation and rapid scanning for maize and other cultigen pollen in lake sediments, which, in conjunction with charcoal and pollen records, is key to determining land-use patterns and the environmental impact of pre-Columbian societies.

Key words; Palynology, Pollen preparation techniques, Cultigen pollen, Zea mays, Pre-Columbian Archaeology, Pre-Columbian agriculture 


\section{A. Introduction}

The pollen of domesticated plants, including maize (Zea mays L.), are key indicators of pre- and postColumbian food production in palaeoecological records throughout South and Central America (Bush et al., 1989, 2007a,b; Islebe et al., 1996; Northrop and Horn, 1996; Behling et al., 1998; Clement and Horn, 2001; Berrio et al., 2000, 2002; Piperno, 2006; Kennedy and Horn, 2008; Niemann and Behling, 2010; Gessert et al., 2011). Maize pollen is particularly advantageous for the detection of food production in the palaeorecord because, although it has been shown to overlap in morphology, notably size, with its ancestor, Balsas teosinte (Zea mays subsp. parviglumis) (Matsuoka et al., 2002; Holst et al., 2007; Piperno et al., 2009; van Heerwaarden et al., 2011), maize pollen can be readily separated from that of other wild grasses by its size, surface sculpturing and exine structure (Holst et al., 2007). However, maize pollen is poorly dispersed from the source plants because of its large size (55- 120 $\mu \mathrm{m}$ ), as shown in both field and laboratory settings (Raynor, 1972; Jarosz et al., 2003), as well as in modern lacustrine environments (Lane et al., 2010). Additional staple food crops common to the Neotropics, such as manioc (Manihot esculenta Crantz), sweet potato (Ipomoea batatas L.), and squash (Cucurbita spp.) can also be useful indicators of food production, although, at present, insufficient studies have been conducted to distinguish the pollen of these domesticated varieties from their wild relatives. Similar to maize, Ipomoea batatas, Cucurbita spp., and Manihot esculenta produce large pollen grains $(80-250 \mu \mathrm{m})($ Herrera and Urrego, 1996), and because they are insectpollinated (Rogers, 1965; Hurd, 1971; Real, 1981; Rival and McKey, 2008), these crops also yield low quantities of pollen.

Thus, key indicators of cultivation are generally rare within lacustrine fossil pollen records (Bush et al., 1989; Behling et al., 1998; Niemann and Behling, 2009), often represented by single grains in noncontiguous horizons, but because of their poor dispersal, large cultigen pollen are considered to be strong indicators of local food production (Bryant and Hall 1993; Jones, 1994; Islebe et al., 1996; Pohl et al., 1996; Bush et al., 2007a; Lane et al., 2010). Palaeoecologists and archaeologists have therefore inferred cultivation from simple presence/absence of these rare pollen grains, rather than quantified variations in abundance afforded by more common pollen types. 
Given that it can be identified to species level, maize pollen is considered to be the strongest evidence of local food production in pre-Columbian archaeological and palaeoenvironmental studies (Clement and Horn, 2001). To increase the likelihood of its detection, palynologists often count outside the standard terrestrial pollen sum (typically 300 grains) (Bush et al., 1989; Clement and Horn, 2001; Anchukaitis and Horn, 2005; Horn and Kennedy, 2001, 2008), which can be a laborious and inefficient task. Even for a lake surrounded by cultivated maize fields, Zea pollen is either rare $(<80$ grains $/ \mathrm{cm}^{3}$ ), or even absent, from standard terrestrial pollen sums (Lane et al., 2010). Also, the number of slides required to be scanned for maize pollen is likely to increase with lake area and distance from the site of cultivation, given these factors are negatively correlated with maize concentrations in lacustrine sedimentary environments (Lane et al., 2010).

A better method that increases the probability of retrieving maize and other large cultigen pollen involves the concentration of these grains using a fine sieve. A detailed methodology has been described for the retrieval of cereal grains in northern Europe (Bowler and Hall, 1989), using a $30 \mu \mathrm{m}$ aperture sieve. However, this methodology suffers from the disadvantage of requiring two sediment samples from a given stratigraphic horizon - one for the standard pollen preparation, and the other specifically for sieving for large cultigen pollen grains. Not only is this double-sample method timeconsuming compared to analysis of a single sample, it is also wasteful of sediment (a sparse commodity from a typical $5 \mathrm{~cm}$ diameter core) that could potentially be used for additional palaeoenvironmental proxy analyses.

\section{A. Aims}

Here, we present a simple sieving methodology for detection of maize and other large cultigen pollen that does not suffer from the drawbacks of a double sampling protocol (Bowler and Hall, 1989). Our method incorporates sieving as an extra key step within a standard chemical digestion pollen protocol 
(Faegri and Iverson, 1989), which markedly increases the likelihood and ease of recovery of maize and other large pollen from staple crops of South and Central America from lake sediments.

\section{A. Study sites}

We tested our methodology on sediments of three lakes from two distinct regions in Latin America, each located near to known archaeological sites (Fig. 1). Lake data are summarized in Table I.

\section{B. Region 1: Northern Belize}

Belize is located in the southeastern part of the Yucatán peninsula, bordered by Mexico to the north, Guatemala to the south and west, and the Caribbean Sea to the east. This country is characterized by extensive pre-Columbian Maya occupation, including Lamanai, a site located in the north-central part of Belize where archaeological evidence points to continuous occupation from $300 \mathrm{BC}$ to AD 1675 AD (Pendergast, 1986; Graham, 2001, 2004). The Maya settlement at Lamanai is located on the west shore of our study site, New River Lagoon (NRL), a substantial open-water body $60 \mathrm{~km}$ from the estuary of New River, one of the largest rivers in northern Belize (Table I). The vegetation at Lamanai is characterized by lowland evergreen broad-leaved forest (Bridgewater et al., 2002). A large swathe of marshy vegetation forms the eastern boundary of the lagoon (Metcalfe et al., 2009; Meerman and Sabido, 2001). Although a lake-level reconstruction from NRL points to shifts in the late Holocene precipitation regime in northern Belize (Metcalfe et al., 2009), there is no archaeological or palaeolimnological evidence of Terminal/Late Classic collapse (ca. AD 750-1050) (Graham, 2004; Metcalfe et al., 2009), unlike neighbouring archaeological sites in Belize (Alcala-Herrera et al., 1994; Jacob and Halmark, 1996), Guatemala (Hodell et al., 2001) and Mexico (Curtis et al., 1996; Hodell et al., 2005).

B. Region 2: Llanos de Moxos, Bolivia 
The Llanos de Moxos is a large hydrological basin $\left(130,000 \mathrm{~km}^{2}\right)$ in SW Amazonia, situated in the Beni department, lowland Bolivia. The Llanos de Moxos is characterized by a mosaic landscape that consists predominantly of seasonally-inundated savannahs, interspersed with forested mounds and river levées (Orellana et al., 2004). Large-scale pre-Columbian earthworks, including habitation mounds, raised fields, canals, causeways and fish weirs (Denevan, 1966; Erickson, 2000; Mann, 2008; Lombardo and Prümers, 2010; Lombardo et al., 2011) have been identified throughout the region. Approximately $50 \mathrm{~km}$ east of Trinidad, the capital of the Beni department, the pre-Columbian earthworks consist of extensive large habitation mounds (> 100), canals and causeways (Lombardo and Prümers, 2010). Situated among these archaeological features, Laguna San José is one of many flat-bottomed and shallow rectilinear lakes dispersed across the Llanos de Moxos (Clapperton, 1993). Two large habitation mounds, Loma Salvatierra and Loma Mendoza, lie within 2 km of Laguna San José, and have been extensively excavated by archaeologists (Prümers 2008, 2009a, 2009b; Lombardo and Prümers, 2010; Dickau et al. 2011). Several additional pre-Columbian earthworks surround the lake, including a canal located within $100 \mathrm{~m}$ of its northwestern shore (Lombardo and Prümers, 2010). Dominant vegetation around Laguna San José includes seasonally-inundated savannahs, some of which are used for cattle pasture. Forest patches are located near the lake shore. Situated approximately $80 \mathrm{~km}$ west of Trinidad, Laguna Isireri is another large, rectilinear lake adjacent to the town of San Ignacio de Moxos. Typical of the northern and western region of the Llanos de Moxos, evidence of pre-Columbian land-use in this area consists of raised field cultivation (Mann, 2008), and several raised fields have been identified adjacent to Laguna Isireri (Saavedra, 2009). Although the local vegetation has been heavily modified in recent centuries, the dominant vegetation in the region is seasonally-inundated savannah, with forest fringing the lake shore. 


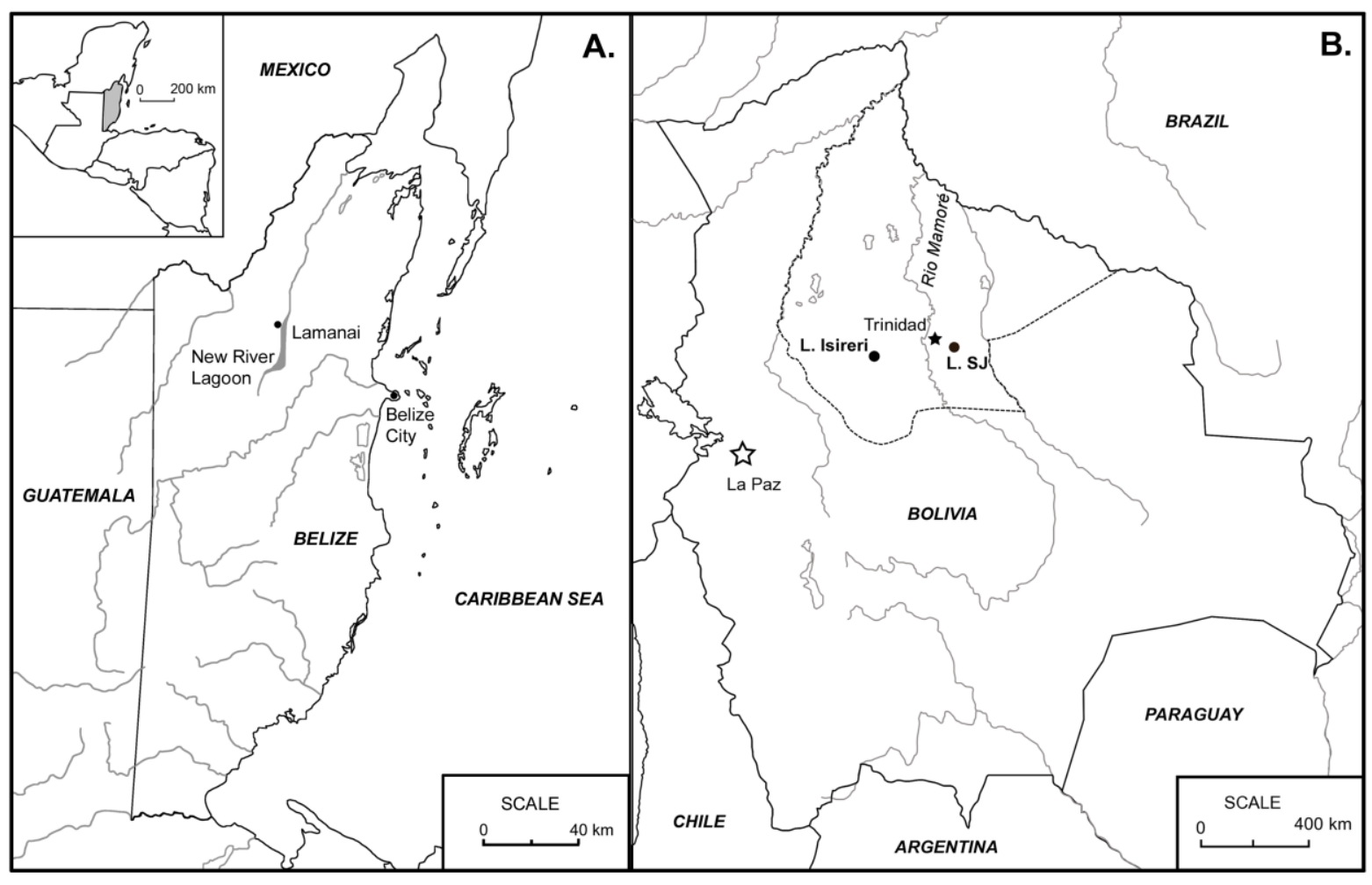

Fig. 1. Location of (a) New River Lagoon, adjacent the Maya settlement at Lamanai, in Belize, and (b)

Lagunas San Jose and Isireri, situated near to habitation mounds and raised fields, respectively, in the

Beni department, lowland Bolivia.

Table I. Site information for the three study lakes, coring location, sediment type, and key archaeological features

\begin{tabular}{|l|l|l|l|l|l|l|l|l|}
\hline & Country & $\begin{array}{l}\text { Core } \\
\text { Location }\end{array}$ & Area & $\begin{array}{l}\text { Water } \\
\text { depth } \\
\text { at core } \\
\text { site }\end{array}$ & $\begin{array}{l}\text { Sediment } \\
\text { type }\end{array}$ & $\begin{array}{l}\text { Archaeology } \\
\text { Dist. of } \\
\text { core to } \\
\text { lake shore }\end{array}$ & $\begin{array}{l}\text { Dist. of shore to } \\
\text { nearest } \\
\text { archaeeological } \\
\text { feature }\end{array}$ \\
\hline $\begin{array}{l}\text { Laguna } \\
\text { San } \\
\text { Jose }\end{array}$ & Bolivia & $\begin{array}{l}14^{\circ} 56^{\prime} 58^{\prime \prime} \mathrm{S} \\
64^{\circ} 29^{\prime} 42^{\prime \prime} \mathrm{W}\end{array}$ & $\begin{array}{l}14.4 \\
\mathrm{~km}^{2}\end{array}$ & $1.0 \mathrm{~m}$ & Clay & $\begin{array}{l}\text { Habitation } \\
\text { mounds, } \\
\text { causeways, } \\
\text { canals }\end{array}$ & $500 \mathrm{~m}$ & $<100 \mathrm{~m}$ \\
\hline $\begin{array}{l}\text { Laguna } \\
\text { Isireri }\end{array}$ & Bolivia & $\begin{array}{l}14^{\circ} 59^{\prime} 16^{\prime \prime} \mathrm{S} \\
65^{\circ} 41^{\prime} 04^{\prime \prime} \mathrm{W}\end{array}$ & $\begin{array}{l}19.0 \\
\mathrm{~km}^{2}\end{array}$ & $1.5 \mathrm{~m}$ & Clay & Raised Fields & $1000 \mathrm{~m}$ & $\begin{array}{l}\text { Several } \\
\text { kilometres }\end{array}$ \\
\hline $\begin{array}{l}\text { New } \\
\text { River } \\
\text { Lagoon }\end{array}$ & Belize & $\begin{array}{l}17^{\circ} 45^{\prime} 09^{\prime \prime} \mathrm{N} \\
88^{\circ} 39^{\prime} 16^{\prime \prime} \mathrm{W}\end{array}$ & $\begin{array}{l}13.5 \\
\mathrm{~km}^{2}\end{array}$ & $2.0 \mathrm{~m}$ & $\begin{array}{l}\text { Organics in } \\
\text { carbonate } \\
\text { matrix }\end{array}$ & $\begin{array}{l}\text { Maya } \\
\text { Settlement } \\
\text { (Lamanai) }\end{array}$ & $<10 \mathrm{~m}$ & $<10 \mathrm{~m}$ \\
\hline
\end{tabular}




\section{A. Methods}

B. Sediment collection

Belize:

The NRL core was taken in 1999 from a jetty adjacent to the Lamanai settlement using a square-rod modified Livingstone piston corer. Four consecutive cores, totalling $319 \mathrm{~cm}$ of sediment, were recovered. Cores were shipped in plastic piping and stored at $4^{\circ} \mathrm{C}$. Details of six radiocarbon dates, reported in Metcalfe et al. (2009), demonstrate the core spans 1800 BC to 1500 AD. Sediments from the NRL core comprise organics within a calcareous matrix, with increasing abundance of silts and clays down core.

\section{Bolivia:}

Surface-sediment coring of the two lakes was performed in June and July 2010 using a $5 \mathrm{~cm}$ diameter Perspex ${ }^{\circledR}$ tube and piston from a floating platform. Surface cores of $31 \mathrm{~cm}$ (San Jose) and $51 \mathrm{~cm}$ (Isireri) were extruded in consecutive $0.5 \mathrm{~cm}$ increments in the field into sealed plastic bags or screwlid bottles, and shipped to the University of Edinburgh where they were stored at $4{ }^{\circ} \mathrm{C}$. Sediments from both cores are clay-rich and contain very little organic matter $(<5 \%)$, as estimated through loss-onignition at $550^{\circ} \mathrm{C}$.

\section{B. Summary of Protocol}

For each of the three study lakes, five pairs of $1 \mathrm{~cm}^{3}$ sediment samples were prepared. For each pair, both samples received identical chemical treatments, but one sample was treated with an extra sieving stage $(53 \mu \mathrm{m})$, while the other control sample, taken from the same stratigraphic horizon, was not sieved. 
Standard chemical digestion protocol was used for the preparation of all fossil pollen samples (Faegri and Iversen, 1989; Bennett and Willis, 2001), including hot 10\% NaOH, 40\% HF (with the exception of NRL), and acetolysis treatments. However, the lengths and types of treatment differed somewhat between lakes, according to differences in sediment lithology. The sequence of chemical treatments performed for each study lake is outlined in Fig. 2. In clayey sediments from the two Llanos de Moxos lakes, sample preparation began with a hot $5 \%$ sodium pyrophosphate treatment to disaggregrate clays (Bates et al., 1978), followed by repeated rinses with water until the supernatant became clear. Hydrofluoric acid and acetylosis treatments followed, after which the samples were passed through a $53 \mu \mathrm{m}$ sieve (details below). The predominantly calcareous sediments from NRL in Belize were initially treated with cold $10 \% \mathrm{HCl}$ until the sample stopped effervescing. New River Lagoon samples were not treated with HF, but instead were treated with hot Calgon ${ }^{\circledR}$, and repeatedly rinsed until the supernatant was clear of suspended clays. Acetolysis followed the removal of clays. After the chemical treatments detailed above had been completed, samples from all three sites were passed through a $53 \mu \mathrm{m}$ sieve, as described below, to isolate the large cultigen pollen grains. 
Lagunas San José \& Isireri

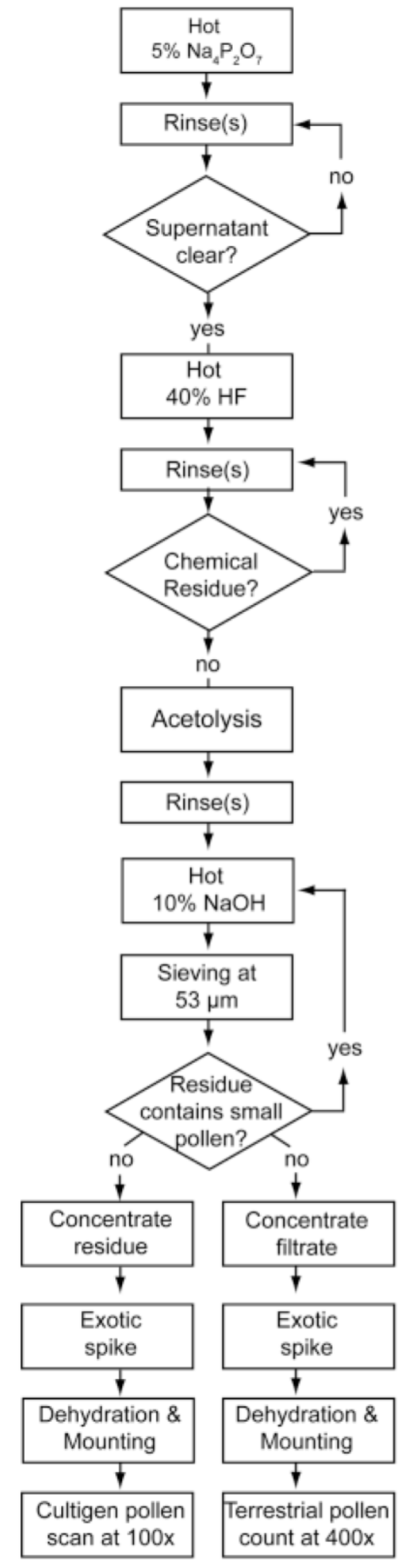

\section{New River Lagoon}

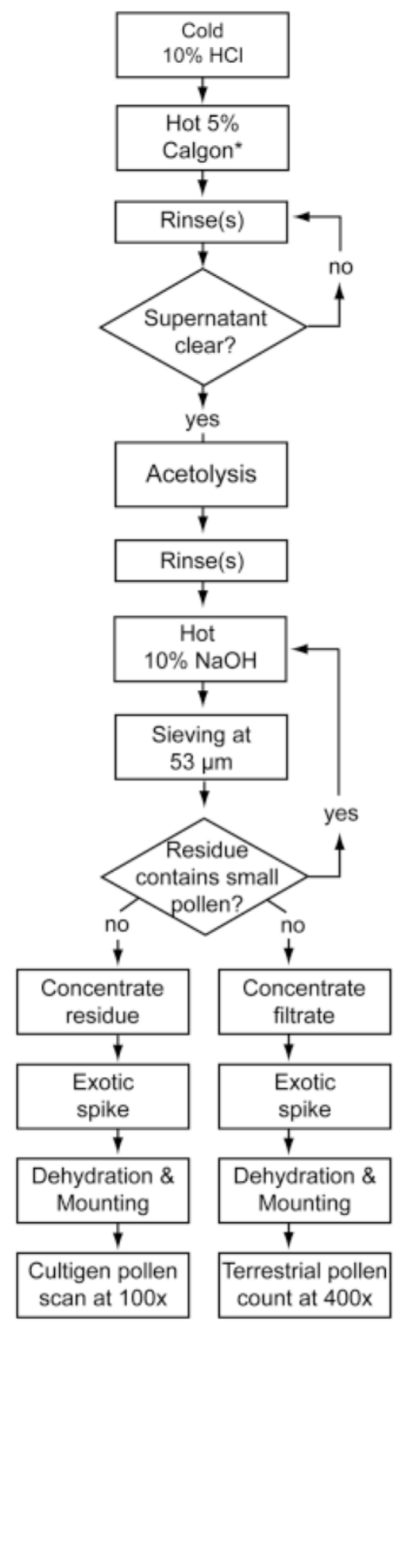

Fig. 2. Flowchart of the pollen preparation method used for each study site, and incorporating the sieving stage. 
B. Isolation of large pollen grains

We used a $53 \mu \mathrm{m}$ aperture sieve to isolate maize and other large cultigen pollen, based on the minimum size of maize pollen in Mesoamerica determined by Holst et al. (2007). Also, pollen of Cucurbita spp., Ipomoea batatas, and Manihot esculenta all have diameters $>80 \mu \mathrm{m}$ (Herrera and Urrego, 1996). Preparations were begun by suspending the pellet in $10 \mathrm{ml}$ of $10 \% \mathrm{NaOH}$, and heating in a boiling water bath for $5 \mathrm{~min}$, stirring occasionally to disaggregate the sample. Samples were transferred to a small beaker, using deionized water to rinse the contents of the tube into the beaker. Approximately $30 \mathrm{ml}$ of water was used to transfer the sample.

The sample was passed through a $53 \mu \mathrm{m}$ brass sieve with a few short blasts of deionized water from a wash bottle, and in doing so, we tried to keep the total volume of filtrate $<100 \mathrm{ml}$. The filtrate was saved for the standard terrestrial pollen count, and the residue was easily washed off the sieve into a $15 \mathrm{ml}$ centrifuge tube, reserved for large $(>53 \mu \mathrm{m})$ pollen grains. The filtrate was concentrated by centrifuging in $15 \mathrm{ml}$ tubes at $3500 \mathrm{rpm}$, decanting, and topping up with additional filtrate until all of the fine fraction was contained in the pellet. All $15 \mathrm{ml}$ tubes, now double the original number, were centrifuged and decanted.

At this stage, we checked to ensure whether the sieving had been successful (Fig. 2). Selected tubes containing the coarse fraction (> $53 \mu \mathrm{m}$ ) of a sample were whirly-mixed, and, using a clean pipette, a small aliquot of the sample was transferred onto a slide and scanned at 100x magnification to check if the sample contained small $(<53 \mu \mathrm{m})$ pollen and/or 'clumped' organic material which binds small pollen and prevents it from passing through the sieve. Although this was rarely the case, if the sieving stage was found to be ineffective, the coarse fraction (residue) can be re-suspended in $10 \% \mathrm{NaOH}$ and re-sieved. The resulting filtrate can be concentrated as above, and combined with the fine fraction from the first sieving attempt. 
After the sieving stage, an equal number of Lycopodium tablets (Stockmarr, 1971) were added to each tube containing the residue and filtrate. The separated coarse and fine fractions were then dehydrated in tertiary-butyl alcohol and mounted in silicone oil for analysis.

\section{B. Pollen Identification and Counting}

The separated coarse and fine fractions were both mounted on slides for analysis. Identifications of all pollen types were made according to published tropical pollen floras (Roubik and Moreno, 1991; Herrera and Urrego, 1996; Colinvaux et al., 1999), a digital tropical pollen database (Bush and Weng, 2007), and a Neotropical pollen reference collection consisting of $>1000$ specimens (collected from herbaria at the 'Noel Kempff Mercado' Natural History Museum in Santa Cruz, Bolivia, and the Royal Botanic Garden Edinburgh (RBGE)), held at the School of Geosciences, The University of Edinburgh. Additional reference literature (Palacios-Chávez et al., 1991) was used for the identification of pollen from Belizean samples, as well as an additional 60 reference specimens of common pollen types of the Yucatán peninsula prepared from herbarium material collected from the RBGE, and held in the School of Geography, the University of Nottingham. The identification of Zea mays was confirmed using the criteria outlined in Holst et al. (2007), including analysis of the distribution of exine intertectile columnellae using phase contrast at 1000x magnification, to distinguish it from the large grains of the genus Tripsacum (Poaceae).

Fine fractions $(<53 \mu \mathrm{m})$ were counted at $400 \mathrm{x}$ magnification for the standard terrestrial pollen count of 300 grains, and coarse fractions (> $53 \mu \mathrm{m}$ ) were counted at 100x magnification for large cultigen pollen grains, in particular, Zea mays (maize), Cucurbita (squash), Manihot (manioc) and Ipomoea batatas-type (sweet potato). Results of cultigen pollen counts from each sample are presented in Table II. Counting the coarse fraction also allowed us to determine the number and type of small $(<53 \mu \mathrm{m})$ pollen grains caught on the sieve that should have been washed through the sieve into the filtrate. This was calculated using the Lycopodium counts of each fraction to relate the standard terrestrial pollen 
count (fine fraction) to the coarse fraction count. However, we found that only a negligible number of small pollen grains were inadvertently caught in the coarse fraction (Table II).

Table II. Results of the coarse (>53 $\mu \mathrm{m}$ ) fraction for each sample analyzed including number of slides scanned for cultigen pollen, the proportion of small $(<53 \mu \mathrm{m})$ pollen grains inadvertently retained within the coarse fractions, and number and type of cultigen pollen recovered. The equivalent terrestrial pollen count refers to the number of pollen grains that the volume of residue scanned would have contained were it unsieved. See 'statistics' for further details.

\begin{tabular}{|c|c|c|c|c|c|}
\hline Sample & $\begin{array}{l}\text { No. of } \\
\text { slides } \\
\text { scanned for } \\
\text { cultigen } \\
\text { pollen }\end{array}$ & $\begin{array}{l}\text { Equivalent } \\
\text { terrestrial } \\
\text { pollen } \\
\text { count }\end{array}$ & $\begin{array}{l}\text { No. of small }(< \\
53 \mu \mathrm{m}) \text { pollen } \\
\text { counted on } \\
\text { slides from } \\
\text { coarse fraction }\end{array}$ & $\begin{array}{l}\text { \% small pollen } \\
\text { on coarse } \\
\text { fraction slides, } \\
\text { relative to } \\
\text { standard count }\end{array}$ & $\begin{array}{l}\text { No. of } \\
\text { cultigen } \\
\text { pollen grains } \\
\text { recovered }\end{array}$ \\
\hline \multicolumn{6}{|l|}{ NRL } \\
\hline 1 & 2 & 1096 & 2 & $0.2 \%$ & nil \\
\hline 2 & 1 & 640 & 0 & 0 & $7 \times$ Z. mays \\
\hline 3 & 2 & 1116 & 5 & $0.4 \%$ & nil \\
\hline 4 & 1 & 505 & 4 & $0.8 \%$ & $5 \times$ Z. mays \\
\hline 5 & 2 & 776 & 8 & $1.0 \%$ & $16 \times$ Z. mays \\
\hline \multicolumn{6}{|c|}{ L. San Jose } \\
\hline 6 & 3 & 2876 & 2 & $0.07 \%$ & nil \\
\hline 7 & 3 & 16168 & 10 & $0.06 \%$ & $2 \times Z$ mays \\
\hline 8 & 2 & 14202 & 29 & $0.20 \%$ & $3 \times Z$. mays \\
\hline 9 & 3 & 23519 & 8 & $0.03 \%$ & $2 \times$ Z. mays \\
\hline 10 & 3 & 33672 & 31 & $0.09 \%$ & $1 \times$ Z. mays \\
\hline \multicolumn{6}{|l|}{ L. Isireri } \\
\hline 11 & 3 & 788 & 4 & $0.5 \%$ & nil \\
\hline 12 & 6 & 6382 & 2 & $0.03 \%$ & nil \\
\hline 13 & 3 & 4943 & 7 & $0.1 \%$ & nil \\
\hline 14 & 3 & 2986 & 4 & $0.1 \%$ & nil \\
\hline 15 & 7 & 1891 & 4 & $0.2 \%$ & $1 \times$ Z. mays \\
\hline
\end{tabular}

Large non-cultigen pollen grains that palaeoecologists would usually include as components of the standard terrestrial pollen count, for example Inga spp. and Annona spp., are also concentrated in the coarse fraction. These grains usually comprise a very low proportion of the pollen sum, but their presence can be of high ecological value for the interpretation of the pollen signal. An exception, however, is Pinus pollen (> $53 \mu \mathrm{m}$ ), which are highly abundant in pollen assemblages from the Yucatan (Bhattacharya et al. 2011), where Pinus caribaea is an ecological dominant of Belizean lowland savannahs. In samples from NRL, this taxon comprises a significant proportion of the terrestrial pollen sum. However, here we included Pinus in the main sum by scanning the coarse fraction for Pinus until the number of Lycopodium spores encountered on the slide was equal to the 
number counted in the fine fraction for the standard terrestrial pollen count. Given that we found an equal count of Lycopodium spores was usually encountered in the first few transects across the coverslip, this is not a time-consuming task. Percent abundance of Pinus determined using this methodology for the sieved NRL samples are compared with standard non-sieved counts in Fig. 3. 


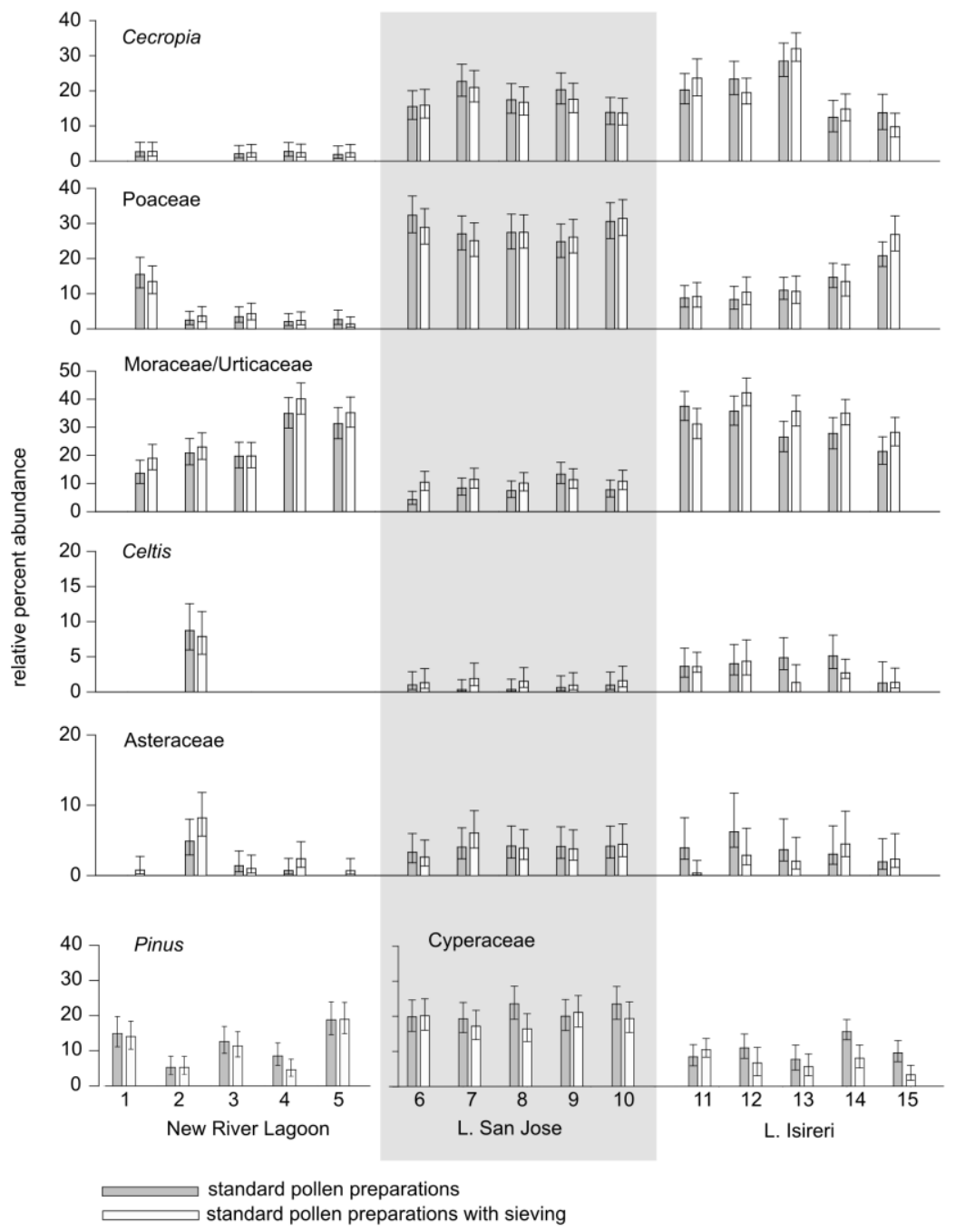

Fig. 3. Bar plots with $95 \%$ confidence intervals comparing sieved and unsieved percent abundances of key taxa found in each study site. Pinus is only present in assemblages from NRL, and Cyperaceae was excluded from the terrestrial sum at NRL because of the abundance of emergent aquatic vegetation at the site. 
B. Statistics

Confidence intervals (95\%) were calculated using the modification of Maher's lognormal distributions method in Psimpoll (Maher, 1972; Bennett, 2007). To relate the volume of sample analyzed from the coarse fraction to that of the standard terrestrial pollen count, or the 'count equivalent' (Table II), the number of Lycopodium spores found on the coarse fraction slide was expressed as a proportion of the Lycopodium count of the main pollen sum. For example, if 100 Lycopodium spores were encountered in the standard terrestrial pollen count and 1000 spores were counted on the coarse fraction slide, then the volume of material on the coarse fraction slide represents 10x the amount of sample analyzed for the standard terrestrial pollen count.

To determine what proportion of small pollen grains $(<53 \mu \mathrm{m})$ were unintentionally retained in the coarse fraction (sieve residue) during preparation, the number of small grains that were encountered in the coarse fraction slide were expressed as a percentage of the main pollen sum using the aforementioned 'count equivalent'. Expanding on the above example, and assuming a standard count of 300 grains, the amount of residue scanned in the coarse fraction is equivalent to a count of 3000 pollen grains. Thus, if 30 small pollen grains were found on the coarse fraction slide, we can estimate that this equates to approximately $1 \%$ of the 300 -grain standard pollen sum (Table II).

\section{A. Results and Analysis}

Our results demonstrate that sieving at $53 \mu \mathrm{m}$ successfully isolates large cultigen pollen grains such as Zea mays (Table II). Although this is the only cultigen pollen type found in the test samples, subsequent use of this technique has yielded Cucurbita (squash) pollen at NRL, and Manihot (manioc) and Ipomoea batatas-type (sweet potato) pollen grains in sediments from an additional study site in French Guiana (unpublished data). 
All three study sites are substantial water bodies and cores from Lagunas Isireri and San José were taken $1000 \mathrm{~m}$ and $500 \mathrm{~m}$ from the lake shore, respectively, to ensure the recovery of a continuous sediment sequence in case of lower lake levels due to past drought (the NRL core was taken within a few metres of the shore, adjacent to the Maya settlement Lamanai). Despite the considerable distance of the core location from shore, which is shown to reduce maize pollen concentrations in the sediment (Lane et al., 2010), we found maize pollen in all samples analyzed from the San José core.

Furthermore, the concentration of large pollen (> $53 \mu \mathrm{m}$ ) by sieving was particularly successful for this site, where in some horizons, the proportion of $1 \mathrm{~cm}^{3}$ sediment sample examined for the coarse fraction equated to over 100x the proportion of the sample examined for the standard terrestrial pollen sum (Table II). It follows then, that even if the samples were scanned outside the standard terrestrial pollen sum, it is highly improbable that any Zea mays grains would have been found at Lagunas San José and Isireri if this additional sieving stage had not been employed.

Zea mays pollen recovery was higher for sediments from NRL, which is unsurprising given the proximity of the core to Lamanai. However, analysis of previously unsieved preparations from NRL revealed no cultigen pollen within the standard terrestrial pollen count, which meant that additional steps were necessary to isolate Zea mays from this site. This could have been achieved by scanning the unsieved preparations outside the pollen sum, but this too would have been very time-consuming, requiring the scanning of numerous additional pollen slide preparations. In contrast, maize pollen was encountered in the first coarse-fraction slide analyzed in our new sieving methodology, thereby considerably reducing the amount of time an analyst needs to invest in searching for evidence of preColumbian cultivation.

Confidence intervals calculated for the paired samples (Bennett, 2007) demonstrate that the added sieving stage does not concentrate small pollen grains such as Cecropia or reduce the relative abundance of larger grains such as Poaceae. Furthermore, whatever small $(<53 \mu \mathrm{m})$ grains are caught in the coarse fraction, they are not disproportionately-represented by any particular pollen type. However, the number of small grains trapped in the coarse fraction is negligible $(<1 \%)$ if care is taken 
to properly digest the sediments prior to sieving. Moreover, the $95 \%$ confidence intervals show tight overlap among the sieved and unsieved pollen percentage values for Pinus in the NRL record, which means that large (>53 $\mu \mathrm{m}$ ) pollen grains can be confidently incorporated into the terrestrial sum using equivalent Lycopodium counts on both fine and coarse fraction slides.

A further key advantage to including our coarse-sieving stage is that the pollen assemblages in the fine fraction are more concentrated, and comprise 'cleaner' preparations, than those for non-sieved samples, making the process of pollen counting significantly faster and easier. To reach a count of 300 terrestrial grains can be relatively time-consuming in the analysis of largely inorganic sediments from large lakes in the Bolivian lowlands where pollen concentrations are often relatively low. Analysis of unsieved samples from NRL was particularly laborious (HF was not used in the preparation of these samples), and in most horizons, an average of seven slides were required to achieve a sum of near to 300 terrestrial grains. However, incorporating our sieving stage $(53 \mu \mathrm{m})$ concentrated the samples such that full counts were reached in only two slides.

\section{A. Recommendations for best sieving practice}

The most important factors in ensuring a good recovery of small $(<53 \mu \mathrm{m})$ pollen grains in the filtrate were: (i) choosing the appropriate chemical treatments for each sediment type, and (ii) sufficient rinsing with deionized water to remove chemical residues after each treatment, particularly HF. Standard chemical digestion protocol (Faegri and Iversen, 1989; Bennett and Willis, 2001) describes a set sequence of stages for the preparation of fossil pollen, often beginning preparations with the hot $\mathrm{NaOH}$ (or $\mathrm{KOH}$ ) treatment. Although this sequence works well for organic samples, such as peat and gyttja, in the case of tropical sediments containing high proportions of clays and silts, the analyst is best served by first tackling the removal of inorganic matter to facilitate further chemical treatments. Secondly, intensive HF treatments (two treatments of $40 \%$ HF for 30 minutes in a hot water bath) are frequently required for lake sediments from tropical regions where the abundance of very small pollen (e.g. Cecropia and Mimosa, $<5 \mu \mathrm{m}$ diameter) precludes the possibility of fine sieving (Cwynar et al., 
1979) for the removal of clays and fine silts. However, the chemical residues from the digestion of silica (fluorosilicates), resulting from intensive HF treatment, often create a sticky black pellet that does not easily disperse in liquid. Although a common solution to the problem of fluorosilicate buildup is the use of a hot $10 \% \mathrm{HCl}$ treatment (Bennett and Willis, 2001), we found that 3-4 rinses in deionized water following the HF treatment removed the chemical residues and allowed the pellet to disperse in liquid. Further care was taken to ensure that all chemical residues were removed after each treatment, thereby ensuring the pellet was not clumped before we proceeded with the sieving step.

We advise against the use of $50 \mathrm{ml}$ centrifuge tubes for concentrating the filtrate without further experimentation to adjust the speed and/or time of centrifugation. Initially, we sieved at $53 \mu \mathrm{m}$ using generous volumes of water $(400-500 \mathrm{ml})$ to get the best pollen recovery in the fine fraction, but this practise diluted the fine fraction to such an extent that concentrating the pellet was difficult. After several rounds of centrifugation in $50 \mathrm{ml}$ tubes, the fine organic material (and with it, small pollen) gathered on the angled sides at the bottom of the tube instead of forming a discrete pellet. This made decanting very difficult, and we lost a sizeable proportion of fine pollen grains, in particular, Cecropia, experimenting with this method. Instead, we found the judicious use of $\sim 100 \mathrm{ml}$ of water, which resulted in a volume of filtrate that can be reasonably concentrated in $15 \mathrm{ml}$ tubes, gave the best results. Also, increasing the centrifuge speed from 3000 to $3500 \mathrm{rpm}$ ensured a better recovery of small grains in the filtrate.

\section{A. Implications for palaeoecology and archaeology in the Americas}

Where palaeoecological studies rely on terrestrial pollen and charcocal records from lake and bog sediments to demonstrate evidence of past land-use practices in archaeological contexts, changing climate can present a complicating story, particularly in regions like the Yucatan peninsula, which has experienced large shifts in its precipitation regime over the past few millennia (Hodell, 1995, 2001; Curtis et al., 1996; Metcalfe et al., 2009), and in the southern hemisphere tropics of South America, where rising precipitation in the late Holocene (Baker et al., 2001; Mayle and Power, 2008) has 
resulted in shifting Amazon forest-savannah boundaries (Mayle et al., 2000; Burbridge et al., 2004). Thus, disentangling the relative impacts of changes in human land-use, climate, and fire regime, upon past vegetation can prove problematic. Crucially, direct evidence of crop cultivation is required to unequivocally demonstrate human land-use in the palaeorecord, but the recovery of large cultigen pollen has often proved difficult due to its rarity in pollen assemblages. Starch grain and phytolith analyses from selected archaeological features and residues from food containers (ceramics, bottle gourds) and plant processing tools (manos, edge ground cobbles, ceramic graters), in addition to combined analysis of phytoliths, pollen and charcoal from lake and wetland sediments, have been successful in addressing this issue (Pearsall et al., 2003; Iriarte et al., 2004; Piperno et al., 2007, 2009; Duncan et al., 2009; Dickau et al., 2011). However, some important food crops, notably Manihot esculenta and Ipomoea batatas, do not produce diagnostic phytoliths (Piperno, 2006). The combination of all three techniques from archaeological contexts and lake sediments provides the most complete picture of the natural environments and plant associations in which the first farming arose (Piperno et al. 2007, 2009; Denham et al., 2003; Ranere et al. 2009) and assessing pre-Columbian land use in palaeoenvironmental studies (Pearsall, 2000), particularly as a lack of comparative pollen morphology studies means that at present, cultivated varieties of domesticated plants (Ipomoea batatas, Manihot esculenta) are palynologically indistinguishable from some of their wild relatives. However, in the absence of these multiproxy analyses, cultigen pollen types in conjunction with evidence of forest clearance and/or disturbance, along with charcoal evidence for anthropogenic fires, is strong evidence of local human activities. Among many research topics, this improved technique for recovering cultigen pollen will allow palaeoecologists and archaeologists alike to maximize their chances of detecting early food-production and assess past human impact on the Neotropics, even in regions where archaeology and archaeobotany are at a very early stage of development. Similarly, it will prove crucial to documenting the practice of early slash-and-burn agriculture (e.g., Piperno et al. 1991), which unlike irrigation canals, raised fields, and agricultural terraces, does not leave visible imprints on landscapes. Lastly, it will help better understand arguably the most dramatic changes in land-use practices since the Pleistocene-Holocene transition brought by the 1492 Columbian Encounter (Turner and Butzer, 1992). 


\section{A. Acknowledgements}

Bolivia: Funding was provided by a Leverhulme Trust research project grant (F/00158/Ch) to FEM and JI, and a NERC doctoral training grant to JC (NE/152830X/1). Thanks to the Museo de Historia Natural 'Noel Kempff Mercado', Santa Cruz, Bolivia, and the 'Programa de Conservación de la Paraba Barba Azul', Trinidad, Beni Department, Bolivia, for logistical and botanical support. Ruth Dickau assisted in the field and Daniel Soto performed botanical surveys at Lagunas Isireri and San Jose. Thanks also to Oscar Saavedra for archaeological field assistance. Belize: The NRL core was extracted as part of a study funded by a NERC PhD studentship (GT4/98/80) (Ann Breen) and a Leverhulme Trust research award (F/158/BQ) (awarded to P.Furley and S. Metcalfe). Thanks to the following for their support: Sarah Metcalfe (University of Nottingham), the Belize Forest Department, Programme for Belize, the people of Lamanai Village and Lamanai Outpost Lodge for permission to do fieldwork. Radiocarbon dating was carried out through a grant in kind from NERC 761.1298.

\section{A. References}

Alcala-Herrera JA, Jacob JS, Machian Castillo ML, Neck RW (1994) Holocene palaeosalinity in Maya wetlands, Belize, inferred from the microfaunal assemblage. Quaternary Research 41, 121-130.

Anchukaitis KJ, Horn SP (2005) A 2000-year reconstruction of forest disturbance from southern Pacific Costa Rica. Palaeogeography Palaeoclimatology Palaeoecology 221, 35-54.

Baker PA, Seltzer GO, Fritz SC, Dunbar RB, Grove MJ, Tapia PM, Cross SL, Rowe HD, Broda JP, (2001) The history of South American tropical precipitation for the past 25,000 years. Science 291, 640-643.

Bates CD, Coxon P, Gibbard PL (1978) New method for preparation of clay-rich sediment samples for palynological investigation. New Phytologist 81, 459-463. 
Bhattacharya T, Beach T, Wahl D (2011) An analysis of modern pollen rain from the Maya lowlands of northern Belize. Review of Palynology and Palaeobotany 164, 109-120.

Behling H, Hooghiemstra H, Negret AJ (1998) Holocene history of the Choco rain forest from Laguna Piusbi, southern Pacific lowlands of Colombia. Quaternary Research 50, 300-308.

Bennett KD (2007) Manual for Psimpoll and Pscomb. Electronic resource. Available at: http://chrono.qub.ac.uk/psimpoll/psimpoll_manual/4.27/psimpoll [accessed 20/10/2011]

Bennett KD, Willis KJ (2001) Pollen In: Smol JP, Birks HJB, Last WM (Eds.) Tracking Environmental Change Using Lake Sediments. Dordrecht, Boston, London: Kluwer Academic Publishers, 5-32.

Berrio JC, Behling H, Hooghiemstra H (2000) Tropical rain-forest history from the Colombian Pacific area: a 4200-year pollen record from Laguna Jotaordo. Holocene 10, 749-756.

Berrio JC, Hooghiemstra H, Marchant R, Rangel O (2002) Late-glacial and Holocene history of the dry forest area in the south Colombian Cauca Valley. Journal Of Quaternary Science 17, 667-682.

Bowler M, Hall VA (1989) The use of sieving during standard pollen pre-treatment of samples of fossil deposits to enhance the concentration of large pollen grains. New Phytologist 111, 511-515.

Bridgewater S, Ibáñez A, Ratter JA, Furley P (2002) Vegetation classification and floristics of the savannahs and associated wetlands of the Rio Bravo Conservation and Management Area, Belize. Edinburgh Journal of Botany 59, 421-442. 
Bryant Jr VM, Hall SA (1993) Archaeological palynology in the United States: a critique. American Antiquity 58, 416-421.

Burbridge RE, Mayle FE, Killeen TJ (2004) Fifty-thousand-year vegetation and climate history of Noel Kempff Mercado National Park, Bolivian Amazon. Quaternary Research 61, 215-230.

Bush MB, Piperno DR, Colinvaux PA (1989) A 6,000 year history of Amazonian maize cultivation. Nature 340, 303-305

Bush MB, Silman MR, de Toledo MB, Listopad C, Gosling WD, Williams C, de Oliveira PE, Krisel C (2007) Holocene fire and occupation in Amazonia: records from two lake districts. Philosophical Transactions of the Royal Society B-Biological Sciences 362, 209-218.

Bush MB, Weng CY (2007) Introducing a new (freeware) tool for palynology. Journal of Biogeography 34, 377-380.

Clapperton C (1993) Quaternary geology and geomorphology of South America. Netherlands: Elsevier Academic Publishers.

Clement RM, Horn SP (2001) Pre-Columbian land-use history in Costa Rica: a 3000-year record of forest clearance, agriculture and fires from Laguna Zoncho. Holocene 11, 419-426.

Colinvaux PA, de Oliveira PE, Moreno Patiño JE (1999) Amazon pollen manual and atlas Amsterdam: Harwood Academic Publishers.

Curtis JH, Hodell DA, Brenner M (1996) Climate Variability on the Yucatan Peninsula (Mexico) during the past 3500 years, and implications for Maya cultural evolution Quaternary Research 46, 3747. 
Denevan WM (1966) The Aboriginal Cultural Geography of the Llanos de Mojos of Bolivia, IberoAmericana. Berkley: University of California Press.

Denham TP, Haberle SG, Lentfer C, Fullagar R, Field J, Therin M, Porch N, Winsborough B (2003) Origins of agriculture at Kuk Swamp in the Highlands of New Guinea. Science 301, 189-193.

Duncan NA, Pearsall DM, Benfer RA (2009) Gourd and squash artifacts yield starch grains of feasting foods from preceramic Peru. Proceedings of the National Academy of Sciences 106:13202.

Erickson CL (2000) An artificial landscape-scale fishery in the Bolivian Amazon. Nature 408, 190193.

Fægri K, Iversen J (1989) Textbook of Pollen Analysis. Chichester and New York: John Wiley.

Gessert S, Iriarte J, Carlos Ríos R, Behling H (2011) Late Holocene vegetation and environmental dynamics of the Araucarua forest region in Misiones Province, NE Argentina. Review of Palaeobotany and Palynology 166 (1-2) 29-37.

Graham E (2001) In the realm of Nachan Kan: Postclassic Maya archaeology at Laguna de On, Belize. Latin American Antiquity 12, 432-434.

Graham E (2004) Lamanai Reloaded: Alive and Well in the Early Postclassic In: Awe J, Morris J, Jones S (eds.) Archaeological Investigations in the Eastern Maya Lowlands, Research Reports in Belizean Archaeology, Volume 1. Belize: Institute of Archaeology, 223-241.

Herrera LF, Urrego LE (1996) Atlas de polen de plantas útiles y cultivadas de la Amazonia Colombiana. Bogotá, Colombia: Fundacion Erigaie. 
Hodell DA, Curtis JH, Brenner M (1995) Possible role of climate in the collapse of Classic Maya civilisation. Nature 375, 391-394.

Hodell DA, Brenner M, Curtis JH, Guilderson T (2001) Solar forcing and the drought frequency in the Maya lowlands. Science 292, 1367-1370.

Hodell DA, Brenner M, Curtis JH (2005) Terminal Classic drought in the northern Maya lowlands inferred from multiple sediment cores in Lake Chichancanab (Mexico). Quaternary Science Reviews 24, 1413-1427.

Holst I, Moreno JE, Piperno DR (2007) Identification of teosinte, maize, and Tripsacum in Mesoamerica by using pollen, starch grains, and phytoliths. Proceedings of the National Academy of Sciences of the United States of America 104, 17608-17613.

Horn SP, Kennedy LM (2001) Pollen evidence of maize cultivation 2700 BP at La Selva Biological Station, Costa Rica. Biotropica 33, 191-196.

Hurd PD Jr, Linsley EG, Whitaker TW (1971) Squash and gourd bees (Peponapis, Xenoglossa) and the origin of the cultivated Cucurbita. Evolution 25, 218-234.

Iriarte J, Holst I, Marozzi O, Listopad C, Alonso E, Rinderknecht A, Montaña J (2004) Evidence for cultivar adoption and emerging complexity during the mid-Holocene in the La Plata basin. Nature $432,614-617$.

Islebe GA, Hooghiemstra H, Brenner M, Curtis JH, Hodell DA (1996) A Holocene vegetation history from lowland Guatemala. Holocene 6, 265-271. 
Jacob JS, Halmark CT (1996) Holocene stratigraphy of cobweb Swamp, a maya wetland in North Belize. Geological Society of America Bulletin 108, 883-891.

Jarosz N, Loubet B, Durand B, McCartney A, Foueillassar X, Huber L (2003) Field measurements of airborne concentration and deposition rate of maize pollen. Agricultural And Forest Meteorology 119, $37-51$.

Jones JG (1994) Pollen evidence for early settlement and agriculture in northern Belize. Palynology 205-211.

Kennedy LM, Horn SP (2008) A late Holocene pollen and charcoal record from La Selva biological station, Costa Rica. Biotropica 40, 11-19

Lane CS, Cummings KE, Clark JJ (2010) Maize pollen deposition in modern lake sediments: A case study from Northeastern Wisconsin. Review of Palaeobotany and Palynology 159, 177-187.

Lombardo U, Prümers H (2010) Pre-Columbian human occupation patterns in the eastern plains of the Llanos de Moxos, Bolivian Amazonia. Journal of Archaeological Science 37, 1875-1885.

Lombardo U, Canal-Beeby E, Fehr S, Veit H (2011) Raised fields in the Bolivian Amazonia: a prehistoric green revolution or a flood risk mitigation strategy? Journal of Archaeological Science 38, $502-512$.

Maher LJ (1972) Nomograms for computing 95\% confidence limits of pollen data. Review of Palaeobotany and Palynology 13, 85-93. 
Matsuoka Y, Vigouroux Y, Goodman MM, Jesus Sanchez G, Buckler E and Doebley J (2002) A single domestication for maize shown by multilocus microsatellite genotyping. Proceedings of the National Academy of Sciences of the United States of America 99 (9), 6080.

Mayle FE, Burbridge R, Killeen TJ (2000) Millennial-scale dynamics of southern Amazonian rain forests. Science 290, 2291-2294.

Mayle FE, Power MJ (2008) Impact of a drier Early-Mid-Holocene climate upon Amazonian Forests. Philosophical Transactions of the Royal Society B-Biological Sciences 363, 1829-1838.

Metcalfe S, Breen A, Murray M, Furley P, Fallick A, McKenzie A (2009) Environmental change in northern Belize since the latest Pleistocene. Journal of Quaternary Science 24, 627-641.

Niemann H, Behling H (2009) Late Holocene environmental change and human impact inferred from three soil monoliths and the Laguna Zurita multi-proxi record in the southeastern Ecuadorian Andes. Vegetation History and Archaeobotany 19, 1-15.

Northrop LA, Horn SP (1996) PreColumbian agriculture and forest disturbance in Costa Rica: Palaeoecological evidence from two lowland rainforest lakes. Holocene 6, 289-299.

Orellana MR, Beck SG, Bourrel L (2004) Unidades mayores de vegetación de las sabanas. In: Pouilly M, Beck SG, Moraes M, Ibañez C (eds.) Diversidad biológica en la llanura de inundacíon del Río Mamoré Importancia ecológica de la dinámica fluvial. Santa Cruz, Bolivia: Centro de Ecología Simón I Patiño, 141-166.

Palacios-Chavéz R, Ludlow-Wiechers B, Villanueva R (1991) Flora Palinologica de la Reserva de la Biosfera de Sian Ka'an, Quintana Roo, Mexico. Chetumal, Quintana Roo, Mexico: Centro de Investigaciones de Quintana Roo. 
Pearsall D (2000) Palaeoethnobotany: A Handbook of Procedures $\left(2^{\text {nd }}\right.$ ed). New York: Academic Press.

Pearsall DM, Chandler-Ezell K, Chandler-Ezell A (2003) Identifying maize in neotropical sediments and soils using cob phytoliths. Journal of Archaeological Science 30, 611-627.

Pendergast DM (1986) Stability through Change: Lamanai, Belize, from the Ninth to the Seventeenth Century. In: Sabloff JA, Wyllys E, Andrews V (eds.) Late Lowland Maya Civilization: Classic to Postclassic. Albuquerque: University of New Mexico Press, 223-249.

Piperno DR (2006) Quaternary environmental history and agricultural impact on vegetation in Central America. Annals of the Missouri Botanical Garden 93, 274-296.

Piperno DR (2006) Phytoliths: A comprehensive guide for archaeologists and paleoecologists. San Diego: AltaMira Press.

Piperno DR, Pearsall DM (1998) The origins of agriculture in the lowland Neotropics. Academic Press. San Diego, California.

Piperno DR, Bush MB, Colinvuax PA (1991) Paleoecological perspectives on human adaptation in central Panama. II the Holocene. Geoarchaeology 6, 227-250.

Piperno DR, Moreno JE, Iriarte J, Holst I, Lachniet M, Jones JG, Ranere AJ, Castanzo R (2007) Late pleistocene and holocene environmental history of the iguala valley, central balsas watershed of Mexico. Proceedings of the National Academy of Sciences 104, 11874-11881. 
Piperno DR, Ranere AJ, Holst I, Iriarte J and Dickau R (2009) Starch grain and phytolith for early ninth millennium B.P. maize from the Central Balsas River Valley, Mexico. Proceedings of the National Academy of Science of the United States of America 106 (13) 5019.

Pohl MD, Pope KO, Jones JG, Jacob JS, Piperno DR, de France SD, Lentz DL, Gifford JA, Danforth ME, Josserand JK (1996) Early agriculture in the Maya lowlands. Latin American Antiquity 355-372.

Prümers H (2009a) ¿"Charlatanocracia" en Mojos? Investigaciones arqueológicas en la Loma Salvatierra, Beni, Bolivia, in: Kaulicke, P., Dillehay, T.D. (Eds.), Procesos y expresiones de poder, identidad y orden tempranos en Sudamérica. Segunda Parte, Lima, pp. 103-116.

Prümers H (2009b) El Proyecto Arqueológico Boliviano-Alemán en Mojos (PABAM) investiga sitios habitacionales prehispánicos en los Llanos de Mojos, Deutches Archäologisches Institut.

Prümers H (2008) Der Wall führt zum See. Die Ausgrabungen 2005-2006 in der Loma Salvatierra (Bolivien). Zeitschrift für Archäologie Außereuropäischer Kulturen 2, 371-379.

Ranere AJ, Piperno DR, Holst I, Dickau R, Iriarte J (2009) The cultural and chronological context of early Holocene maize and squash domestication in the Central Balsas River Valley, Mexico. Proceedings of the National Academy of Sciences 106, 5014-5018.

Raynor GS, Ogden EC, Hayes JV (1972) Dispersion and deposition of corn pollen from experimental sources. Agronomy Journal 64, 420-427.

Real LA (1981) Nectar availability and bee-foraging on Ipomoea (Convolvulaceae). Biotropica 13, 64-69. 
Rival L, McKey D (2008) Domestication and diversity in manioc (Manihot esculenta Crantz ssp. esculenta, Euphorbiaceae). Current Anthropology 49, 1119-1128.

Rogers DJ (1965) Some botanical and ethnological considerations of Manihot esculenta. Economic Botany 19, 369-377.

Rosenmeier MF, Hodell DA, Brenner M, Curtis JH, Guilderson TP (2002) A 4000-year lacustrine record of environmental change in the southern Maya lowlands, Peten, Guatemala. Quaternary Research 57, 183-190.

Roubik DW, Moreno PJE (1991) Pollen and Spores of Barro Colorado Island, Monographs in Systematic Botany, Vol. 36. Missouri: Missouri Botanical Garden.

Saavedra O (2009) Culturas Hidráulicas de la Amazonia Boliviana. La Paz, Bolivia: Oxfam.

Stockmarr J (1971) Calcium tablets with spores used in absolute pollen analysis. Pollen et Spores 13, 615-621.

Turner B, Butzer KW (1992) The Columbian Encounter and Land-Use Change. Environment 34, 1644.

van Heerwaarden J, Doebley J, Briggs WH, Glaubitz JC, Goodman MM, de Jesus Sanchez Gonzalez J, Ross-Ibarra, J (2011) Genetic signals of origin, spread, and introgression in a large sample of maize landraces. Proceedings of the National Academy of Sciences 108, 1088. 